Vol. 9 (2000): 149-155.

\title{
Short term behavioural consequences of denied access to environmental facilities in mink
}

\author{
Claus Peter Bjælke Hansen and Leif Lau Jeppesen \\ Zoologisk Institut, Kфbenhavns Universitet, Tagensvej 16, DK-2200 København N, Denmark, \\ e-mail: cpbhansen@zi.ku.dk
}

\begin{abstract}
The aim of this study was to investigate whether farm mink denied access to water for swimming became more frustrated than animals denied access to an empty cage. Also the relative importance of water for swimming, the empty cage and the nest box was measured. Seventy-eight farm mink were placed in four groups according to a $2 \times 2$ experimental design: two unit sizes, large and small, and two water conditions, with or without water. Each unit consisted of three cages side by side in which half of the animals had a water filled basin and the other half an empty area in the middle cage. This cage had openings to the other two cages. In addition, a tunnel above the basin connected the right and left cage. One hour before the beginning of daily observations the animals had their access restricted to only the left cage. Each animal was observed ten times a day on nine consecutive days.

No difference in scratching into the tunnel, basin or nest box was detected between the four groups. All groups scratched significantly or nearly significantly more into the nest box than into both the tunnel and the basin. Most stereotypies were found in the group in small cages with a dry basin. Our investigation suggests that when compared to the deprivation from a nest box, the deprivation of water for swimming does not alone cause frustration of farm mink any more that the exclusion from an empty cage. However, it does indicate that the cage size may affect the level of stereotypy.
\end{abstract}

Key words: welfare, stereotypy, swimming, deprivation

\section{Introduction}

The needs of a domesticated animal may not be relevant to its fitness but are relevant to its welfare because they involve a strong motivation (Weary and Fraser 1995). The Motivation for certain behavioural patterns may be so strong that if their expression is not allowed the welfare of the animal may be jeopardized (Duncan 1998).
That is why behavioural needs should be considered in the housing and management of farm animals (Hoy 1995). Since in the wild, mink (Mustela vison) are highly associated with water ways and get a large proportion of their food from these resources (Dunstone 1993), it may be argued that swimming has a high functional value in mink as an appetitive behaviour. In addition, water for swimming could be an element in thermoregulatory behaviour. This has led to a

(C) Agricultural and Food Science in Finland

Manuscript received September 1999 


\section{AGRICULTURAL AND FOOD SCIENCE IN FINLAND}

\section{Hansen, C.P.B. \& Jeppesen, L.L. Behavioural consequences of denied access in mink}

debate about swimming being a behavioural need in farm mink. If so, it follows that if minks at farms are not given access to water for swimming their welfare is affected.

In order to investigate this question, our group has kept mink with access to water for swimming together with a control group since 1995. Previously, we have looked at differences in reproduction (Skovgaard et al 1997a) and behaviour (Skovgaard et al 1997b) when unmanipulated. The aim of the present experiment was to investigate the behaviour of mink when denied access to resources usually present in their environment. This was done both by the comparison between denied access to water and denied access to an empty compartment. Both cases were compared with the simultaneous deprivation from a third resource, the nest box. Lack of nest boxes is known to lead to an increase in stress hormones (Hansen and Brandt 1989, Hansen and Damgaard 1991). Though this may not tell how long term deprivation can affect the animals, it may contribute to the understanding of how the animals value the different resources when under the acute stress of being denied access to part of the normally accessible area. As an indicator of motivation to obtain a resource, we used the amount of scratching on barriers blocking entry to the resources. This parameter was chosen as the animals normally would scratch to get access to a restricted area. During standard farm routines the animals are sometimes barred temporarily from some areas of their units which prompts the animals to scratch on the barrier. On occasions their scratching lead to them regaining access by themselves and if not the barrier will eventually be removed. Hence, the animals should connect scratching with regaining access.

\section{Material and methods}

\section{The animals}

Sixty-two female and sixteen male farm mink were placed in four groups according to a $2 \times 2$ experimental design: two cage sizes, large (L) and small (S), and two water conditions, with water $(\mathrm{W})$ and without water $(\mathrm{D}=\mathrm{dry})$. Housing units (Fig. 1) consisted of either three standard mink cages (each length $900 \mathrm{~mm} \mathrm{x}$ width 300 $\mathrm{mm} x$ height $450 \mathrm{~mm}, 0.27 \mathrm{~m}^{2}$ and $0.12 \mathrm{~m}^{3}$ ) or three larger fox cages (each length $1200 \mathrm{~mm} x$ width $650 \mathrm{~mm} x$ height $750 \mathrm{~mm}, 0.78 \mathrm{~m}^{2}$ and $0.59 \mathrm{~m}^{3}$ ). The left cage included a nest box, the middle cage a basin covering the entire floor and the right cage was empty. Forty of the mink were housed in the large units, thirty-eight in the small ones. The connection between the left and the right cage was through either the basin in the middle cage or a wire mesh tunnel above the basin. In nineteen of the small and twenty of the large units the basin was filled with water and with a few exceptions, cleaned and refilled once a week. This left us with the following four group: WL $(\mathrm{N}=20)$, WS $(\mathrm{N}=19), \mathrm{DL}(\mathrm{N}=20)$ and DS $(\mathrm{N}=19)$. If an animal wanted to go through the middle cage with a water basin, it had to dive into the water. In each group the proportions of males to females were the same. At the time of the experiment (the summer of 1997) the mink were one or two years of age and had been born and raised in their present environment.

\section{Procedure}

Observations were carried out in September 1997. One hour before the beginning of daily observations the animals had their access to the nest box and both the middle and the right cages barred. The behavioural data were collected using the scanning method (Simpson and Simpson 1977) with ten scans with an interval of $10 \mathrm{~min}$ between each scan. Half of the animals were scanned in the morning, the other half in the afternoon. The order was reversed every day. Each animal was observed ten times a day on nine consecutive days. At the end of each day the barriers were removed. Feeding took place in the left cage at midday between the two observation periods of the day.

The behavioural parameters collected were: 
Stereotypy as defined by Ödberg (1978), Inactive, Scratching on the barrier to the tunnel, Scratching on the barrier to the middle cage, Scratching on the barrier to the nest box or Other Activities. All elements except Inactive were combined into the category Activity. The various stereotypies are described in Table 1. For some calculations the three types of scratching were combined into Scratching (all). Only frequencies were used and were collected using Psion Workabout ${ }^{\mathrm{TM}}$ and calculated on the SAS@ ver. 6.0 package. Stereotypies were expressed both as frequencies of observations and as proportion of Activity. Due to the scan sampling procedure employed and since group data violated assumptions of parametric statistical tests, distribution-free methods were applied throughout. By comparing combinations of groups the effect of the cage sizes (WS+DS vs. WL+DL) and the water conditions (WS+WL vs. DS+DL) on the behavioural parameters was tested. The combined effect of cage size and water conditions was tested by comparing the four groups directly.

\section{Results}

The barriers to the nest boxes received between two and five times as many scratches as did the barriers to the middle cages and the tunnels. It was not possible to detect any difference among

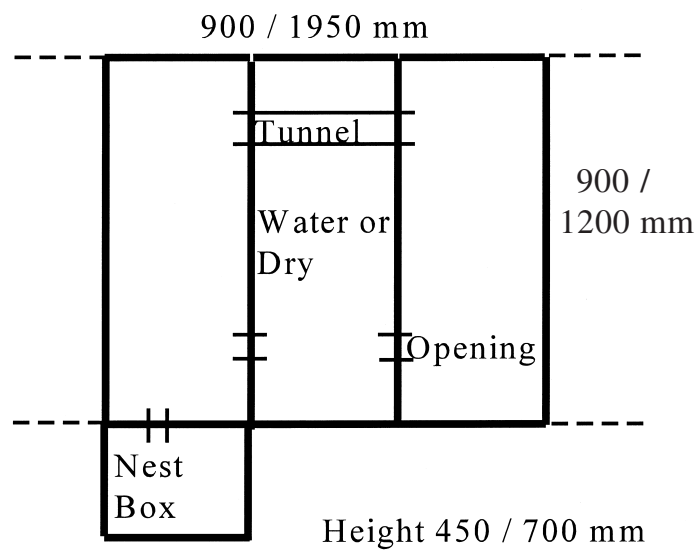

Fig. 1. Layout of cage units.

the four experimental groups with regard to scratching on the barrier to the nest box, the middle cage or the tunnel (Table 2). Except for mink in the large units without water (DL, $\mathrm{P}=0.068$ ), each group, on average, scratched significantly less on the barrier to the middle cage than on the barrier to the nest box. Scratching into the tunnel was also significantly lower than into the nest box, except for the group in the small units and with no water (DS) which did not show any significant difference in scratching $(\mathrm{P}=0.076)$. The two non-significant results had the same direction as the others. Mink in large units did more total scratching on barriers than mink in small units. It is also worth noting that there was as much scratching into dry middle cages as there was into water filled basins.

Table 1. Descriptions of the various stereotypes.

\begin{tabular}{ll}
\hline Biting & Stereotyped intensive biting in the wiremesh. \\
Horizontal & Stereotyped side to side movement of the anterior body with the posterior part still. \\
Vertical & Stereotyped up and down movement of the anterior body with the posterior part still. \\
Nipple & Stereotyped circular movement with the head around or nearby the drinking nipple. \\
Pendling & Stereotyped end-to-end of cage movement of the whole body. \\
Bottom & Like Pendling but with simultaneous snout-circling directed towards the cage floor. \\
Mixed Stereotype & Like Pendling but with vertical stereotyped movement at one or both ends of the cage. \\
Horizontal circling & Stereotyped circling on the cage floor. \\
Vertical circling & Stereotyped running floor-wall-ceiling-wall. \\
Jumping & Stereotyped up and down movement of the entire body.
\end{tabular}




\section{AGRICULTURAL AND FOOD SCIENCE IN FINLAND}

\section{Hansen, C.P.B. \& Jeppesen, L.L. Behavioural consequences of denied access in mink}

Table 2. Observations of 90 scannings over four groups (WL, WS, DL and DS) plus combined water conditions (Water and Dry) and combined cage sizes (large and Small). Probabilities refer to neighbouring columns. Tests are Mann-Whitney Utests. Probability levels: Not significant: $-, 0.01<\mathrm{P}<0.05: *, 0.001<\mathrm{P}<0.01$ : **, $\mathrm{P}<0.001$ : ***.

\begin{tabular}{|c|c|c|c|c|c|c|c|c|c|c|c|c|}
\hline \multirow[b]{2}{*}{$\mathrm{N}$} & \multicolumn{5}{|c|}{ Groups: } & & \multicolumn{2}{|c|}{ Water Conditions } & & \multicolumn{2}{|c|}{ Cage Sizes } & \\
\hline & $\begin{array}{l}\text { WL } \\
(20)\end{array}$ & $\begin{array}{l}\text { WS } \\
(19)\end{array}$ & & $\begin{array}{c}\text { DL } \\
(20)\end{array}$ & $\begin{array}{c}\text { DS } \\
(19)\end{array}$ & & $\begin{array}{c}\text { Water } \\
\text { (39) }\end{array}$ & $\begin{array}{l}\text { Dry } \\
(39)\end{array}$ & & $\begin{array}{c}\text { Large } \\
(40)\end{array}$ & $\begin{array}{c}\text { Small } \\
(38)\end{array}$ & \\
\hline \multicolumn{13}{|c|}{ Mean Numbers of Observations of Scratching into } \\
\hline Nest Box & 11.9 & 8.8 & - & 10.0 & 7.1 & - & 10.4 & 8.6 & - & 11.0 & 8.0 & - \\
\hline Middle Cage & 2.3 & 1.5 & - & 4.4 & 2.4 & - & 2.2 & 3.2 & - & 3.3 & 2.2 & - \\
\hline Tunnel & 2.4 & 2.1 & - & 4.2 & 2.3 & - & 1.9 & 3.4 & - & 3.3 & 2.0 & - \\
\hline \multicolumn{13}{|c|}{ Mean (in \%) of Proportion of Stereotypy } \\
\hline & 9.2 & 13.8 & - & 13.4 & 41.7 & $* * *$ & 11.4 & 27.2 & * & 11.3 & 27.7 & $* * *$ \\
\hline \multicolumn{13}{|c|}{ Mean Numbers of Observations of } \\
\hline Activity & 48.8 & 58.2 & - & 49.0 & 64.3 & ** & 53.4 & 56.4 & - & 48.9 & 61.2 & $* *$ \\
\hline Scratching & 16.6 & 12.4 & - & 18.5 & 11.8 & - & 14.5 & 15.2 & - & 17.5 & 12.1 & * \\
\hline Stereotypes & 5.1 & 9.6 & - & 7.9 & 27.3 & $* * *$ & 7.3 & 17.4 & * & 6.5 & 18.5 & $* * *$ \\
\hline
\end{tabular}

Also, in no group was there any difference between scratching into the tunnel and into the middle cage.

The level of Activity was higher in the small than in the large units. This holds for both the combined small groups and for the dry groups (DL vs. DS). Though not significant the results of the water groups (WL vs. WS) pointed in the same direction. The absolute and proportional level of stereotypy was influenced the same way. There was more stereotypy in the small units in the dry group (DS) and in the small groups combined; for the water group alone there was a nonsignificant tendency in the same direction (WS $>$ WL). Both measures of stereotypies were also more frequent $(\mathrm{P}<0.01$ and $\mathrm{P}<0.001$ respectively, $\mathrm{P}$-values not indicated in the table) in the small dry groups (DS) as compared to the small water group (WS) and in the combined dry group. The significant differences concerning stereotypies were mainly caused by a very high proportional level of Stereotypy $(\bar{x}=41.7 \%)$ in the group of mink in small units with a dry middle cage (DS). This result was not caused by one or two extremely stereotyping animals. Only one animal in this group did not perform stereotyped behaviour compared to six in the group in small units with water in the middle cage.

\section{Discussion}

The present experiment can be seen as a kind of a preference test where the animals could choose to gain access to the three facilities: 1) the nest box, 2) the tunnel and the right cage and 3) the middle cage (+/- water) and the right cage. It can be argued that previous experience may affect the outcome of such tests (Duncan 1992) but because the animals had equal experience with the facilities, their previous experience should not have interfered with the results. If their amount of scratching was taken as a workload or cost to be paid for a reward, then the animals were prepared to pay much more for access to the nest box than for access to any of the other facilities including the water-filled basin. This might indicate that, in the present design, access to the nest box is a greater need than access to the other facilities. Therefore the result suggests that there are situations in which access to the nest box is more important for the welfare of the animals than the access to water for swimming or an empty compartment. Whether this is also the case in other and more general situations remain to be seen. Some support of this comes from Cooper and Mason (1997) using consumer 
Vol. 9 (2000): 149-155.

demand models. They found the mink to work the hardest to get access to the familiar home cage.

Still based on the assumption of scratching being indicative of need to get access, the animals in our experimental setup did not demonstrate greater need for gaining access to water for swimming than for getting access to an empty room. This suggests that if water for swimming is an independent need, it is not greater then the need for an empty room. At least not when at the same time the animal is denied access to the nest box. It may have been because the shelter of the nest box was of more importance than the presence of water for swimming.

The main influence of the experimental conditions on the frequency of stereotyped behaviour was to increase the frequency in the small dry group (DS). This increase affected the results in the combined groups leading to a higher frequency of stereotypies in the dry group and the small group. The frequency was two to three times higher in these groups than in the water group and the large group. It was also twice as high as in a previous investigation on the mink's undisturbed behaviour in the present design (Skovgaard et al 1997b, Hansen and Jeppesen 2000). This suggests that at least the additional amount of stereotypies was induced by the frustration imposed by the present design. Other authors have found that if an animal is deprived of a need, frustration will occur (Sambraus 1985, Hughes and Duncan 1988, Poole 1992) which could lead to the expression of stereotypies (Vestergaard 1998). As reviewed by Mason (1991) factors which can "trigger, prolong or increase the rate of repetition of an established stereotypy" are often stressful or frustrating. Therefore, on the assumption that frustration induced stereotypies are an expression of bad welfare (Mason 1991, Duncan et al 1993), the small units and especially the small and dry units (DS) may be considered worse for the acutely experienced welfare in the present design. The basis for showing more frustration-induced stereotypies may be that the animals showing them are more prone to do so due to a more perma- nent exposure to sub-optimal conditions. If this is so, the results also suggest that the small and dry environment has a negative long-term effect on the welfare. Concerning the dryness aspect, this suggestion find no support in previous result and it should therefore be examined further. Concerning the cage size aspect, the suggestion is supported by the previous findings of higher frequencies of stereotypies in the small cages (Skovgaard et al 1997b). Also, in an experiment with five different cage sizes ranging from 0.10 $\mathrm{m}^{2}$ to $1.06 \mathrm{~m}^{2}$, Hansen (1988) found the mink in the largest cages to show the least stereotypy. However, no effect on the physiological stress parameters could be found (Hansen and Brandt 1989) and a later experiment with other animals failed to confirm the findings published in 1988 (Hansen et al 1994). Similarly, Hansen and Damgaard (1991) could not confirm an impact of cage size on the level of stress hormones and Jonasen (1987) failed to find a link between level of stereotypy and cage size. Obviously, more studies are needed both on the effect of cage size and the relationship between this and both induced and unprovoked stereotypies.

Other studies have shown that an increase in stereotypy behaviour in farm mink may be linked to an increase in the level of activity (Jonge et al 1986, Bildsøe et al 1990, Jeppesen and Falkenberg 1990, Hansen 1993). In accordance with this, both the present study where the cage designs were manipulated and our previous investigations in the present design under unmanipulated situations (Skovgaard et al 1997b, Hansen 1999) show the highest level of activity in the small unit.

In conclusion our investigation suggests that in the present design, and maybe also in more general situations, the nest box is more important for the welfare of the mink than water for swimming or an empty compartment. Water for swimming and an empty compartment on the other hand seems equally important. Animals in the small cages performed more stereotypies during our experiment which might reflect a lower welfare in these cages. 


\section{AGRICULTURAL AND FOOD SCIENCE IN FINLAND}

\section{Hansen, C.P.B. \& Jeppesen, L.L. Behavioural consequences of denied access in mink}

\section{References}

Bildsøe, M., Heller, K.E. \& Jeppesen, L.L. 1990. Stereotypies in adult ranch mink. Scientifur 14: 169-177.

Cooper, J.J. \& Mason, G. 1997. The behavioural priorities of mink (Mustela vison) in a closed economy. Proceedings of the British Society of Animal Society Winter Meeting 1997: paper 17.

Duncan, I.J.H. 1992. Measuring preferences and the strength of preferences. Poultry Science 71: 658663.

- 1998. Behavior and behavioral needs. Poultry Science 77: 1766-1772.

- , Rushen, J. \& Lawrence, A.B. 1993. Conclusions and Implications for Animal Welfare. In: Lawrence, A.B. \& Rushen, J. (eds.). Stereotypic Animal Behaviour. CAB International, Wallingford, UK. p. 193-206.

Dunstone, N. 1993. The Mink. T and A D Poyser Ltd., London.

Hansen, C.P.B. 1993. Stereotypies in ranch mink: the effect of genes, litter size and neighbours. Behavioural Processes 29: 165-178.

- 1999. Normal Behaviour of Ranch Mink With Access to Swimming Water. Proceedings of Nordic ISAE Winter Meeting at Flämslätt 1999.

- \& Jeppesen, L.L. 2000. The Swimming Activity of Farm Mink (Mustela vison) and its Relation to Stereotypies. Acta Agriculturæ Scadinavica Section A Animal Science (in press).

Hansen, S.W. 1988. Effect of variable cage size and lacks of admission to nest box on the behaviour, physiology and production of mink kits. In: Murphy, B.D. \& Hunter, D.B. (eds.). Biology, Pathology and Genetics of Fur Bearing Animals. 4th International Scientific Congress in Fur Animal Production: Rexdale, Canada. p. 153-163.

- \& Brandt, A. 1989. Effect of cage size and nest box on the haematological/ enzymological status and physiological stress levels in mink kits. Scientifur 13: 185-192.

- \& Damgaard, B. 1991. Effect of environmental stress and immobilization on stress physiological variables in farmed mink. Behavioural Processes 25: 191-204.

-, Hansen, B.K. \& Berg, P. 1994. The effect of cage environment and ad libitum feeding on the circadian rhythm, behaviour and feed intake of farm mink. Acta Agriculturae Scandinavica Section A Animal Science 44: $120-127$.

Hoy, S. 1995. Requirements for the housing and management of animals from a behavioral-perspective. Tierarztliche Umschau 50: 456.

Hughes, B.O. \& Duncan, I.J.H. 1988. The notion of ethological "need", models of motivation and animal welfare. Animal Behaviour 36: 1696-1707.

Jeppesen, L.L. \& Falkenberg, H. 1990. Effects of playball on peltbiting, behaviour and the level of stress in Ranch Mink. Scientifur 14: 179-186.

Jonasen, B. 1987. Adfærdsforsøg med burstørrelser til mink. Statens Husdyrbrugsforsøg - Meddelelse 652: $1-5$.

Jonge, G. de, Carlstead, K. \& Wiepkema, P.R. 1986. The Welfare of Ranch Mink. COVP: Beekbergen.

Mason, G.J. 1991. Stereotypies: a critical review. Animal Behaviour 41: 1015-1037.

Ödberg, F.O. 1978. Animal Behaviours: Stereotypies. In: 1st World Congress in Ethology and Applied Zootechnology. p. 475-480.

Poole, T.B. 1992. The Nature and Evolution of Behavioural Needs in Mammals. Animal Welfare 1: 203220.

Sambraus, H.H. 1985. Stereotypies. In: Fraser, A.F. (ed.). Ethology of farm Animals. Elsevier, Amsterdam. p. 431-441.

Simpson, M.J.A. \& Simpson, A.E. 1977. One-zero and scan methods for sampling behaviour. Animal Behaviour 25: 726-731.

Skovgaard, K., Jeppesen, L.L. \& Hansen, C.P.B. 1997a. Would you like a swim, Madam Mink? Scientifur 21: 247-251.

Skovgaard, K., Jeppesen, L.L. \& Hansen, C.P.B. 1997b. The effect of swimming water and cage size on the behaviour of ranch mink (Mustela vison). Scientifur 21: 253-259.

Vestergaard, K.S. 1988. Discussion 2. Applied Animal Behaviour Science 19: 366.

Weary, D.M. \& Fraser, D. 1995. Signalling need - costly signals and animal-welfare assessment. Applied Animal Behaviour Science 44: 159-169. 
Vol. 9 (2000): 149-155.

\title{
SELOSTUS
}

\section{Eräiden ympäristövirikkeiden saatavuuden estämisen välittömät vaikutukset tarhaminkin käyttäytymiseen}

\author{
Claus Peter Bjælke Hansen ja Leif Lau Jeppesen \\ Kööpenhaminan yliopisto, Tanska
}

Tutkimuksen tarkoituksena oli selvittää, kumpi turhauttaa tarhaminkkiä enemmän, uimaan pääsyn estäminen vai tyhjään häkkiin pääsyn estäminen. Myös uintimahdollisuuden, tyhjän häkin ja pesäkopin suhteellista merkitystä minkille mitattiin. 78 tarhaminkillä oli käytössään kolme häkkiä. Häkit olivat joko suuria tai pieniä ja keskimmäisessä häkissä oli joko vedellä täytetty tai tyhjä allas, ja nämä vaihtoehdot olivat tarjolla kaikkina neljänä mahdollisena yhdistelmänä, 19-20 eläintä/ryhmä. Eläimet pääsivät häkistä toiseen joko häkkien seinissä olevien aukkojen kautta tai äärihäkistä toiseen keskimmäisen häkin läpäisevän yhdystunnelin kautta. Eläimet teljettiin vasempaan häkkiin sulkemalla yhdystunneliin, keskial- taaseen ja pesäkoppiin johtavat aukot ja niiden käyttäytymistä tarkkailtiin tunnin kuluttua aukkojen sulkemisesta yhdeksänä perättäisenä päivänä.

Neljän ryhmän välillä ei huomattu eroja pyrkimisessä tunneliin, keskihäkkiin tai pesäkoppiin. Kaikki ryhmät pyrkivät enemmän pesäkoppiin kuin tunneliin tai keskihäkkiin. Eniten stereotypiaa esiintyi ryhmässä pienet häkit ja vedetön keskihäkki. Tutkimuksen perusteella voidaan sanoa, että pelkkä uimaan pääsyn estäminen ei aiheuta tarhaminkin turhautumista yhtään enempää kuin tyhjään häkkiin pääsyn estäminen. Kuitenkin voidaan päätellä, että häkin koko saattaa vaikuttaa stereotyyppisen käyttäytymisen esiintymiseen. 
AGRICULTURAL AND FOOD SCIENCE IN FINLAND 